\title{
Snow heterogeneous reactivity of bromide with ozone lost during snow metamorphism
}

\author{
Jacinta Edebeli ${ }^{1,2}$, Jürg C. Trachsel ${ }^{3}$, Sven E. Avak ${ }^{1}$, Markus Ammann ${ }^{1}$, Martin Schneebeli ${ }^{3}$, Anja Eichler ${ }^{1,4}$, and \\ Thorsten Bartels-Rausch ${ }^{1}$ \\ ${ }^{1}$ Laboratory of Environmental Chemistry, Paul Scherrer Institut, Villigen PSI, Switzerland \\ ${ }^{2}$ Swiss Federal Institute of Technology, ETH Zürich, Zurich, Switzerland \\ ${ }^{3}$ WSL Institute for Snow and Avalanche Research SLF, Davos Dorf, Switzerland \\ ${ }^{4}$ Oeschger Centre for Climate Change Research, University of Bern, Bern, Switzerland
}

Correspondence: Thorsten Bartels-Rausch (thorsten.bartels-rausch@psi.ch)

Received: 21 February 2020 - Discussion started: 22 April 2020

Revised: 2 August 2020 - Accepted: 31 August 2020 - Published: 12 November 2020

\begin{abstract}
Earth's snow cover is very dynamic on diurnal timescales. The changes to the snow structure during this metamorphism have wide-ranging impacts on processes such as avalanche formation and on the capacity of surface snow to exchange trace gases with the atmosphere. Here, we investigate the influence of dry metamorphism, which involves fluxes of water vapour, on the chemical reactivity of bromide in the snow. To this end, the heterogeneous reactive loss of ozone in the dark at a concentration of $5 \times 10^{12}-6 \times$ $10^{12}$ molec. $\mathrm{cm}^{-3}$ is investigated in artificial, shock-frozen snow samples doped with $6.2 \mu \mathrm{M}$ sodium bromide and with varying metamorphism history. The oxidation of bromide in snow is one reaction initiating polar bromine releases and ozone depletion. We find that the heterogeneous reactivity of bromide is completely absent from the air-ice interface in snow after $12 \mathrm{~d}$ of temperature gradient metamorphism, and we suggest that the burial of non-volatile bromide salts occurs when the snow matrix is restructuring during metamorphism. Impacts on polar atmospheric chemistry are discussed.
\end{abstract}

\section{Introduction}

Snow on Earth hosts chemical reactions that impact the composition of the atmosphere (Dominé and Shepson, 2002; Grannas et al., 2013). One example is the oxidation of bromide and the subsequent release of bromine from Arctic snow (Abbatt et al., 2010; Saiz-Lopez and von Glasow,
2012). This reactive halogen species participates in ozonedestroying chemical cycles in the gas phase. Ozone is one of the main oxidants in the lower atmosphere and impacts atmospheric composition, human health, and climate (Simpson et al., 2007). Recent improvements to global atmospheric chemistry models indicate that halogen chemistry accounts for about $14 \%$ of the global tropospheric ozone sinks (Schmidt et al., 2016). In addition, reactive halogen species are potent oxidants for organics and gas-phase mercury, the latter of which is of particular interest (Simpson et al., 2007, 2015). Oxidized mercury readily partitions into condensed phases; from these phases, it may enter the ocean and the food web upon seasonal snow melt (Steffen et al., 2008).

Dominé et al. (2008) argued that the efficient chemical reactivity in snow is linked to its physical properties. Snow is a porous matrix that is dense enough to provide a large surface area for heterogeneous reactions, but it is not too dense to limit transport and light penetration (which is seen in mediums such as soil). The heterogeneous oxidation of bromide by ozone, which is a potential pathway for bromine release under both dark and sunlit conditions (Abbatt et al., 2010), has been shown to be very efficient on ice and brine surfaces (Wren et al., 2010; Oldridge and Abbatt, 2011; Edebeli et al., 2019). The high oxidation rates on aqueous solutions have been linked to an ozonide intermediate and its stabilization at the surface (Artiglia et al., 2017). As bromide needs to be accessible to gas-phase ozone for efficient heterogenous oxidation, the location of these chemical reactants - their distribution between the air-ice interface and other reservoirs in the 
interior of the snow - is a key determinant of their chemical reactivity (Bartels-Rausch et al., 2014; Hullar and Anastasio, 2016; McFall et al., 2018). Field studies have revealed a high heterogeneity in bromine release and bromide concentration in snow, and they have attributed this heterogeneity to the initial source of bromide and to post-depositional changes in its location (Jacobi et al., 2012; Pratt et al., 2013).

One prominent post-depositional mechanism is dry metamorphism, as it shapes the structure and physical properties of snow and impacts heat transfer, albedo, and avalanche formation (Blackford, 2007; Dominé et al., 2008; Schweizer, 2014). Snow at the Earth's surface that is exposed to varying temperature gradients with time undergoes continued sublimation and deposition during metamorphism with complete rebuilding of the entire snow matrix every few days (Pinzer et al., 2012). Earth's snow cover can be exposed to temperature gradients between 10 and $100{ }^{\circ} \mathrm{C} \mathrm{m}^{-1}$ (Birkeland et al., 1998). Dominé et al. (2015) showed that such temperature gradient conditions can prevail on a seasonal scale: in the low-Arctic tundra, snow is exposed to a temperature gradient that is mostly above $20^{\circ} \mathrm{C} \mathrm{m}^{-1}$ between mid-November and early February. The consequences of this are changes in the isotopic composition of the snow with implications for ice core dating (Steen-Larsen et al., 2013, 2014; Ebner et al., 2017). Further, Hagenmuller et al. (2019) observed dust particles being incorporated into the ice matrix of snow driven by intensive water vapour fluxes during dry, temperature gradient metamorphism.

Due to the turnover of snow grains and the movement of water vapour, contaminants may be redistributed between the surface and bulk of the snow grains: studies investigating the adsorption and uptake of trace gases such as nitric acid and hydrochloric acid with growing ice have observed higher uptake than in ice at equilibrium (Kärcher and Basko, 2004; Ullerstam and Abbatt, 2005; Kippenberger et al., 2019). Kippenberger et al. (2019) showed that the burial of volatile acids is a strong function of acidity, growth rate, and temperature. At equilibrium, the adsorption of acidic trace gases leads to the acids or their anions entering the ice phase at considerable concentration only within the interfacial region at a depth of a few nanometres, as recently observed for hydrochloric acid and volatile organic acids (Krepelova et al., 2013; BartelsRausch et al., 2017; Kong et al., 2017; Waldner et al., 2018).

Therefore, recrystallization in snow might have a significant impact on the fraction of contaminants or reactants located at the air-ice interface of snow and, in turn, on the heterogeneous chemistry of ions in snow. Laboratory studies investigating temperature gradient metamorphism effects in natural and artificial snow have observed a strong influence of metamorphism on the elution behaviour of ions such as ammonium, fluoride, chloride, calcium, and sulfate. Whereas calcium and sulfate were found to be enriched at the air-ice or ice-ice interface during snow metamorphism, ammonium, fluoride, and chloride were buried in the bulk of the snow
(Hewitt et al., 1989, 1991; Cragin et al., 1996; Trachsel et al., 2019).

Here, we study the effect of sublimation and growth of ice during snow metamorphism on bromide reactivity in wellcontrolled laboratory experiments. The sodium bromide used in this study is non-volatile, and field studies have related its mobility in the snowpack to its vivid photochemical transformation into volatile bromine. Bromine is released to the air and may redeposit on the snow surface after the formation of stickier bromine compounds (Toom-Sauntry and Barrie, 2002). The objective of this study is to investigate the heterogeneous reactivity of bromide oxidation by gas-phase ozone in the dark. To assess the surface concentration of bromide and its change during temperature gradient metamorphism, the gas-phase ozone loss is monitored in this study. Bromide concentration in the doped snow samples $(6.2 \mu \mathrm{M})$ is typical for snow on Arctic sea ice (Pratt et al., 2013).

\section{Experimental}

Snow samples were prepared by shock freezing aqueous solutions (Bartels-Rausch et al., 2004; Trachsel et al., 2019) and were stored in a metamorphism box with a well-defined temperature gradient at the WSL Institute for Snow and Avalanche Research SLF in Davos (Trachsel et al., 2019). After exposure to the temperature gradient, the structurally intact individual samples were exposed to ozone in a packedbed flow tube set-up in order to derive the impact on the reactivity with gas-phase ozone (Bartels-Rausch et al., 2004). The structure of snow samples before and after metamorphism was imaged using X-ray microtomography (Trachsel et al., 2019).

\section{Sample preparation}

Artificial snow was produced by spraying and shock freezing droplets of a sample solution in liquid nitrogen using a homemade sprayer (Bartels-Rausch et al., 2004; Trachsel et al., 2019). The samples were left overnight at $-45^{\circ} \mathrm{C}$ and then stored isothermally at $-5^{\circ} \mathrm{C}$ for $7 \mathrm{~d}$ to anneal and to minimize internal grain-boundaries (Blackford, 2007; Riche et al., 2012). The samples were returned to $-45^{\circ} \mathrm{C}$ after this isothermal treatment to retard further changes with time and were stored for up to $54 \mathrm{~d}$ at $-45^{\circ} \mathrm{C}$ prior to the metamorphism experiments to reach a quasi-steady state. The snow was sieved using pre-cleaned stainless-steel sieves (Retsch, Germany) in a $-20{ }^{\circ} \mathrm{C}$ cold laboratory at the WSL Institute for Snow and Avalanche Research SLF (Davos, Switzerland). Snow grains in the size range from 300 to $600 \mu \mathrm{m}$ were packed into $12.0 \pm 0.1 \mathrm{~cm}$ long, $2.4 \pm 0.1 \mathrm{~cm}$ i.d. (internal diameter) glass reactor tubes.

The sample solution was either ultrapure water (18 M $\Omega$ quality, arium pro, Sartorius, Göttingen, Germany; for the undoped snow) or an aqueous sodium bromide ( $\mathrm{NaBr}$, Sigma 
Aldrich, $>99.0 \%$ ) solution in ultrapure water (for the doped snow). The bromide concentration in the sieved snow crystals was $6.2 \pm 0.18 \mu \mathrm{M}(498 \pm 14 \mathrm{ppbw})$ in the doped snow and $<0.12 \mu \mathrm{M}(<10 \mathrm{ppb})$ in the undoped snow, as determined by ion chromatography (Metrohm, Herisau, Switzerland; 850 Professional IC, 872 Extension Module, 858 Professional Sample Processor autosampler). A Metrosep A Supp 10 column (Metrohm) was used, and the eluents were a $1.5 \mathrm{mM} \mathrm{Na}_{2} \mathrm{CO}_{3}$ and $0.3 \mathrm{mMNaHCO}_{3}$ in a $1: 1$ mixture followed by $8 \mathrm{mM} \mathrm{Na}_{2} \mathrm{CO}_{3}$ and $1.7 \mathrm{mM} \mathrm{NaHCO}_{3}$ in a $1: 1$ mixture with a flow rate of $0.9 \mathrm{~cm}^{3} \mathrm{~min}^{-1}$. Possible instrumental drifts were monitored by measuring a standard after every 20th sample.

\section{Metamorphism}

For the temperature gradient metamorphism experiments, samples were exposed to a gradient of $31^{\circ} \mathrm{C} \mathrm{m}^{-1}$ for $12 \mathrm{~d}$ in a snow metamorphism box mounted in a cold room at $-8^{\circ} \mathrm{C}$ (at SLF, Davos, Switzerland). The metamorphism box was a heavily insulated box with a heating plate set to $-4{ }^{\circ} \mathrm{C}$ at the bottom. Over this plate, there was a $\sim 2-3 \mathrm{~cm}$ thick layer of ice from ultrapure water. The sample holders were mounted on a disc with a $0.5 \mathrm{~cm}$ layer of ice made with ultrapure water that was in contact with the snow grains in order to increase thermal contact (Pinzer and Schneebeli, 2009). The spaces between the sample tubes were filled by sieving snow in. The box was then covered with a thin plastic film that was in contact with the filled-in snow and the caps of the samples in order to avoid losses due to sublimation. This set-up resulted in an effective temperature at the bottom and top of the snow samples of $-4.4 \pm 0.1$ and $-8.1 \pm 0.1^{\circ} \mathrm{C}$ respectively.

After the temperature gradient metamorphism treatment, the samples were stored at $-45^{\circ} \mathrm{C}$. For comparison, additional samples were stored isothermally at $-20^{\circ} \mathrm{C}$ at SLF (Davos, Switzerland) for $12 \mathrm{~d}$. In total, 12 samples were prepared from the homogenized snow batches: 2 undoped and 2 doped samples that experienced $12 \mathrm{~d}$ temperature gradient metamorphism, 2 undoped and 2 doped samples without temperature gradient metamorphism, and 2 undoped and 2 doped samples that experienced isothermal metamorphism. Two replica samples - those of the doped snow that was exposed to temperature metamorphism for $12 \mathrm{~d}$ and the replica of the undoped snow that was not exposed to temperature gradient metamorphism - could not be analysed due to technical failures during the experiments.

Structural changes in the samples were assessed using an $\mathrm{X}$-ray computer microtomography scanner (Scanco microCT 40) with a resolution of $10 \mu \mathrm{m}$. This microCT was operated at $-20^{\circ} \mathrm{C}$. Details of the microCT scan operations are given in Pinzer and Schneebeli (2009). The reconstructed microCT images were filtered with a Gaussian filter (support 2 voxels, standard deviation 1 voxel), and the threshold for segmentation was applied according to Hagenmuller et al. (2014).
Structural parameters of the segmented ice structure were extracted with the software tools of the microCT device (Image Processing Language, Scanco Medical) to calculate the porosity and specific surface area.

\section{Packed bed flow tube experiments}

Samples were exposed to ozone at $-15^{\circ} \mathrm{C}$. Before exposure, about $2 \mathrm{~cm}$ of the samples was scraped off from the top and bottom of the samples to avoid potential contamination from contact with the ice layer on the disc in the metamorphism box or the caps of the sample holder. An exception to this was one of the $0 \mathrm{~d}$ doped samples, where $3 \mathrm{~cm}$ was shaved off. Afterwards, the mass of each snow sample during the ozone exposure was determined based on the weight of the filled and empty sample tube. The sample tubes were placed in the reactor cell, an insulated cooling jacket, at $-15^{\circ} \mathrm{C}$. The sample was allowed to temperature equilibrate for $1 \mathrm{~h}$ before exposure to gases. Humidified airflow of $\sim 200 \mathrm{~cm}^{3} \mathrm{~min}^{-1} \mathrm{O}_{2}$ and $\sim 200 \mathrm{~cm}^{3} \mathrm{~min}^{-1} \mathrm{~N}_{2}$ was delivered through the sample for $30 \mathrm{~min}$ to condition the sample. The total flow rate through the sample was set to between 339 and $352 \mathrm{~cm}^{3} \mathrm{~min}^{-1}$ at a normal temperature and pressure of $273.15 \mathrm{~K}$ and 1013.25 bar respectively. This airflow was humidified to a water vapour pressure of ice at $-15.0 \pm 0.3^{\circ} \mathrm{C}$.

Ozone was generated by passing the $\mathrm{N}_{2} / \mathrm{O}_{2}$ airflow through a pen ray Hg UV lamp. The ozone flow was also humidified before delivery to the sample. The ozone flow was alternated between a bypass and the sample to control for drifts in the ozone concentration. The ozone concentration was monitored using a commercial analyser (Teledyne, Model 400E). The average ozone concentration for each experiment was slightly different due to the day-to-day variability in the efficiency of the ozone generator. For all experiments, the ozone concentrations varied from 163 to $212 \mathrm{ppb}$ $\left(4.7 \times 10^{12}-6.2 \times 10^{12}\right.$ molec. $\left.\mathrm{cm}^{-3}\right)$. The maximum variability during any one experiment was less than $5 \mathrm{ppb}$ after attaining initial stability at the start of the experiment. This drift was accounted for during analysis using fitting routines.

To confirm perfect flow conditions in the packed bed flow tubes, the chromatographic retention of acetone was determined for some samples at $-30^{\circ} \mathrm{C}$. Once the ozone experiment was finished, the samples were exposed to a flow of acetone in humidified $\mathrm{N}_{2}$ (Bartels-Rausch et al., 2004). The observed retention time of acetone at $-30{ }^{\circ} \mathrm{C}$ matched calculations based on the air-ice partitioning coefficient (Dominé and Rey-Hanot, 2002; Winkler et al., 2002; Peybernes et al., 2004; Bartels-Rausch et al., 2005; Crowley et al., 2010) and the specific surface area of the snow sample as derived by microCT measurements for the undoped and doped samples after temperature gradient metamorphism. 


\section{Results and discussion}

Figure 1 shows the ozone loss rates for snow samples prior to and after exposure to dry metamorphism. The ozone loss rate was derived based on observed changes in the gas-phase ozone concentration downstream of the flow tube packed with the snow sample. The ozone loss curves can be classified into three regions:

1. All samples show a high $\left(>9 \times 10^{12}\right.$ molec. $\left.\mathrm{s}^{-1}\right)$ loss rate during the initial period of ozone exposure up to $500 \mathrm{~s}$. This observed loss is attributed to the reaction of ozone with traces of impurities, to a delay due to switching the gas flows, and to the residence time of the ozone gas in the porous snow, and it is not analysed further.

2. In the intermediate time regime from about 500 to $8000 \mathrm{~s}$, the ozone loss rate is largest for the two samples doped with $6.2 \mu \mathrm{M}$ bromide prior to ageing under laboratory-controlled temperature gradient metamorphism with $4 \times 10^{12}$ and $7 \times 10^{12}$ molec. $\mathrm{s}^{-1}$ at a 1000 s ozone exposure duration (Fig. 1, blue lines, open circles). The loss rate was reduced by a factor of about 4-7 in the snow sample that experienced temperature gradient metamorphism with $1 \times 10^{12}$ molec. $\mathrm{s}^{-1}$ at a $1000 \mathrm{~s}$ ozone exposure duration (Fig. 1, yellow line, open squares). This loss rate is indistinguishable from that in the samples without added bromide with a mean of $1 \times 10^{12}$ molec. $\mathrm{s}^{-1}$ and with a standard deviation of $0.4 \times 10^{12}$ molec. $\mathrm{s}^{-1}$ at $1000 \mathrm{~s}$ for five samples (Fig. 1, grey line, open diamonds). Also shown is the loss rate from two samples that experienced isothermal metamorphism for $12 \mathrm{~d}$ at $-20^{\circ} \mathrm{C}$ (Fig. 1, red lines, open triangles). The loss rate is only slightly reduced compared with the samples before exposure to metamorphism, strongly supporting the driving role of the temperature gradient.

3. After about $8000 \mathrm{~s}$ of ozone exposure, the ozone loss rates of all experiments approach zero loss of ozone. The raw data curves levelled off approaching a steady loss rate of $1.1 \times 10^{12}-1.9 \times 10^{12}$ molec. $\mathrm{s}^{-1}$. This background loss rate may be attributed to the reactive uptake of ozone to ice that is driven by a self-reaction on the ice surface (Langenberg and Schurath, 1999), which is the main phase in the frozen solution samples investigated here. Langenberg and Schurath (1999) described a reactive ozone uptake coefficient on ice of $7.7 \times 10^{-9}$ $8.6 \times 10^{-9}$ at $-15^{\circ} \mathrm{C}$ and at ozone gas-phase concentrations similar to those in our work. The uptake coefficient normalizes the loss rate to the collision rate of ozone with the ice (or snow) surface. A loss rate of $0.86 \times 10^{12}-0.90 \times 10^{12}$ molec. $\mathrm{s}^{-1}$ can be derived based on the reported uptake coefficient for the experimental conditions of our doped samples prior to metamorphism, which is in good agreement with our observa-

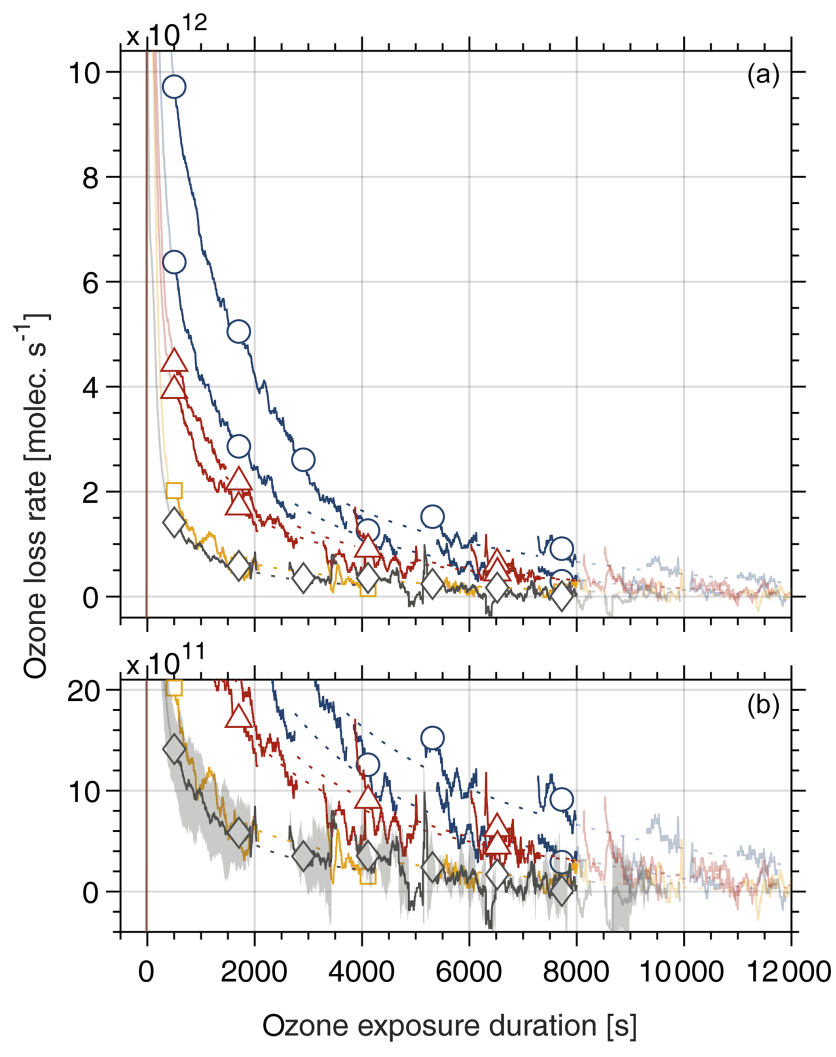

Figure 1. Ozone loss rate with duration of exposure. The snow samples with a bromide concentration of $6.2 \mu \mathrm{M}$ experienced $0 \mathrm{~d}$ (blue lines, open circles) and $12 \mathrm{~d}$ (yellow line, open squares) of metamorphism with a temperature gradient of $31^{\circ} \mathrm{C} \mathrm{m}^{-1}$. Panel (b) is a zoomed-in view of the data in panel (a). Ozone data were recorded continuously (lines), and the markers are guides. The dotted lines are a guide for the eyes for periods when ozone loss data were not available (see text for details). Also shown are the ozone loss rates of snow samples after $12 \mathrm{~d}$ of isothermal metamorphism at $-20^{\circ} \mathrm{C}$ (red lines, open triangles). The grey line (open diamonds) denotes the average ozone loss rates of five samples with no bromide added and with and without exposure to temperature gradient metamorphism. The shaded area in panel (b) shows the standard deviation. The gas-phase mixing ratio of ozone varied between $4.7 \times 10^{12}$ and $6.2 \times 10^{12}$ molec. $\mathrm{cm}^{-3}$ for individual samples. The temperature during ozone exposure was $-15^{\circ} \mathrm{C}$. At time 0 , ozone in the carrier gas was passed over the snow samples.

tions. Because this loss rate is not related to the bromide in the samples, it has been subtracted from the data discussed and shown in Fig. 1.

\section{Ozone loss compared to previous work}

The reaction of gas-phase ozone with frozen solutions containing bromide has been studied in great detail previously (Wren et al., 2010, 2013; Oldridge and Abbatt, 2011; Abbatt et al., 2012). Oldridge and Abbatt (2011) described 
coated wall flow tube studies on frozen sodium bromidesodium chloride-water mixtures at $-15^{\circ} \mathrm{C}$, and Wren et al. (2010) reported on a laser-induced fluorescence study with sodium bromide-water mixtures at $-20^{\circ} \mathrm{C}$. The studies by Wren et al. (2010) and by Oldridge and Abbatt (2011) were done with an initial sodium bromide concentration of $10 \mathrm{mM}$ and a gas-phase ozone concentration of $1 \times 10^{14}$ and $80 \times 10^{14}$ molec. $\mathrm{cm}^{-3}$ respectively. Oldridge and $\mathrm{Ab}$ batt (2011) argued that this multiphase reaction proceeds in the liquid fraction of sample containing bromide brine that is in equilibrium with ice between $0^{\circ} \mathrm{C}$ and the eutectic temperature where the salt precipitates. The eutectic temperature of sodium bromide is at or below $-28^{\circ} \mathrm{C}$ (Stephen and Stephen, 1963).

The concentration of sodium bromide in the reactive solutions in equilibrium with ice is a sole function of temperature; thus, sodium bromide has a concentration of $3.4 \mathrm{M}$ during ozone exposure at $-15^{\circ}$ - even for our samples that were frozen from aqueous solutions with $6.2 \mu \mathrm{M}$ bromide. For this calculation, the freezing point depression data by Stephen and Stephen (1963) and Rumble (2019) were used.

Despite the differences in the concentration of bromide in the solutions used to freeze the films, the similar concentration of bromide in the brine during ozone exposure makes a comparison of the experimental results feasible. For the comparison, the respective reported uptake coefficients of $1.5 \times 10^{-8}$ and $2 \times 10^{-8}-4 \times 10^{-8}$ from Wren et al. (2010) and Oldridge and Abbatt (2011) were transferred into loss rates based on the specific surface area of the snow sample used in this work and an ozone concentration of $4.7 \times 10^{12}$ $6.2 \times 10^{12}$ molec. $\mathrm{cm}^{-3}$. The loss rate prior to temperature gradient metamorphism found in the work presented here agrees with the loss rates of $2 \times 10^{12}-6 \times 10^{12}$ molec. $s^{-1}$ derived based on these earlier experimental works. Uncertainty in this comparison comes from the very low ozone concentration of $5 \times 10^{12}$ molec. $\mathrm{cm}^{-3}$ used in this study. Based on the results from Oldridge and Abbatt (2011), one would expect increasing surface reaction rates with lower ozone concentrations. Further, the surface coverage and the volume of the reactive sodium bromide brine at the interface might vary significantly due to differences in the sample geometries and sample preparation. Please note that we refrain from discussing the results as an uptake coefficient in this work, as generally only the specific surface area of the snow is known (that of the reactive brine is unknown).

\section{Location of impurities}

The striking loss of heterogeneous reactivity during temperature gradient metamorphism raises questions regarding the location of the reactive bromide in the shock-frozen, artificial snow samples before metamorphism. Snow can host impurities in several compartments (Bartels-Rausch et al., 2014): chemical species (besides water) and ions can be molecu- larly embedded within the ice matrix (solid solution) and molecularly adsorbed at the air-ice interface; in liquid or solid patches at the air-ice interface; and in micro-pockets within the ice matrix, including the ice-ice interface (at grain boundaries). Clearly, only bromide in direct contact with the gas phase, which is located at the air-ice interface or within the bulk at a distance that allows sufficient diffusion to the interface, is accessible to gas-phase ozone and, in turn, reactive. In the following, we elaborate on the feasibility of bromide being hosted in these distinct departments in the samples used here.

Shock freezing aqueous solutions may also preserve the homogeneous distribution of solutes in the ice matrix; bromide might then diffuse from the ice matrix to the air-ice interface and heterogeneously react with the ozone. In the following, this reacto-diffusive loss is estimated. Due to lack of knowledge regarding the diffusion coefficient of bromide in ice, the diffusion coefficient of $\mathrm{HNO}_{3}$ in crystalline ice at $-15^{\circ} \mathrm{C}$ of $100 \times 10^{-12} \mathrm{~cm}^{2} \mathrm{~s}^{-1}$ (Thibert and Dominé, 1998) was used as an upper limit in this calculation, and the diffusion coefficient of $\mathrm{HCl}$ at $-15^{\circ} \mathrm{C}$ of $3 \times 10^{-12} \mathrm{~cm}^{2} \mathrm{~s}^{-1}$ was used as a lower bound. Further, the aqueous concentration of $6.2 \mu \mathrm{M}$ and the specific surface area of each snow sample as derived by the microCT data (Table 1) was used. Based on these assumptions, one may estimate that the total amount of bromide diffusing from the ice bulk to the surface is $0.2 \times 10^{10}-1.6 \times 10^{10}$ molec. $\mathrm{s}^{-1}$. This is much less than the ozone loss observed in our experiments, clearly showing that bromide is not present homogeneously in the ice matrix of the snow samples after shock freezing.

Exclusion of bromide to the air-ice interface during freezing has been observed by others at higher concentration (Wren et al., 2010). We find exclusion of bromide from the rapidly growing ice during shock freezing even though the aqueous concentration is significantly lower than the typical solubility limits for ions in ice (details below), which might also be related to kinetic effects during fast ice growth. Thibert and Dominé $(1997,1998)$ derived maximum solubilities of 0.1 to $1 \mathrm{mM}$ for $\mathrm{HCl}$ and 0.06 to $0.6 \mathrm{mM}$ for $\mathrm{HNO}_{3}$ in ice at -8 to $-35^{\circ} \mathrm{C}$. These data describe the equilibrium between gas-phase acid and solid solution and may serve as an estimate for the solubility limit of sodium bromide in ice. Thus, even though it is very likely that the ice might hold $6.2 \mu \mathrm{M}$ of bromide as solid solution (the total amount of bromide divided by the total ice volume), the measured ozone loss rates indicate that sufficient amounts of bromide to form brine are excluded to the air-ice interface after shock freezing.

We propose that the brine forms liquid patches on the surface and filaments along the grain boundaries at the interface, as observed for more concentrated frozen salt solutions (Blackford et al., 2007). A homogenous film covering the total snow surface is unlikely: a back-of-the-envelope calculation with the total amount of bromide doped to the samples and with a concentration of $3.4 \mathrm{M}$ gives a brine layer with a thickness of only $\sim 0.1 \mathrm{~nm}$ at $-15^{\circ} \mathrm{C}$ for the specific surface 
Table 1. Settings for the snow samples; the number of days gives the duration of metamorphism. Br denotes the concentration of bromide as derived by ion chromatography; SSA is the specific surface area as derived from the microCT scans with an typical error of $\pm 6 \%$ (Kerbrat et al., 2008). The density was derived based on the weight of the snow sample and the volume of the sample holder. The mass denotes the amount of snow during the ozone exposure experiments, and the surface area denotes the total surface area of the snow during the ozone exposure experiments. The experiments with added bromide and an average of the five experiments with no added bromide are shown in Fig. 1 and discussed in this work.

\begin{tabular}{l|rrrrr}
\hline Metamorphism, duration, and conditions & $\begin{array}{r}\mathrm{Br} \\
(\mu \mathrm{M})\end{array}$ & $\begin{array}{r}\text { SSA } \\
\left(\mathrm{cm} \mathrm{g}^{-1}\right)\end{array}$ & $\begin{array}{r}\text { Density } \\
\left(\mathrm{g} \mathrm{cm}^{-3}\right)\end{array}$ & $\begin{array}{r}\text { Mass } \\
(\mathrm{g})\end{array}$ & $\begin{array}{r}\text { Surface area } \\
\left(\mathrm{cm}^{2}\right)\end{array}$ \\
\hline $0 \mathrm{~d}$ & 6.2 & 183 & 0.33 & 17 & 3118 \\
$0 \mathrm{~d}$ & 6.2 & 183 & 0.32 & 11 & 2018 \\
$12 \mathrm{~d}, 31^{\circ} \mathrm{C} \mathrm{cm}^{-1}$ gradient & 6.2 & 162 & 0.41 & 14 & 2268 \\
$12 \mathrm{~d}$, isothermal & 6.2 & 143 & 0.45 & 16 & 2281 \\
$12 \mathrm{~d}$, isothermal & 6.2 & 143 & 0.35 & 14 & 1996 \\
$0 \mathrm{~d}$ & $<0.12$ & 195 & 0.35 & 13 & 2540 \\
$0 \mathrm{~d}$ & $<0.12$ & 195 & 0.30 & 10 & 1953 \\
$0 \mathrm{~d}$ & $<0.12$ & 176 & 0.30 & 12 & 2113 \\
$12 \mathrm{~d}, 31^{\circ} \mathrm{C} \mathrm{cm}^{-1}$ gradient & $<0.12$ & 167 & 0.37 & 14 & 2336 \\
$12 \mathrm{~d}, 31^{\circ} \mathrm{C} \mathrm{cm}^{-1}$ gradient & $<0.12$ & 167 & 0.39 & 17 & 2836 \\
\hline
\end{tabular}

area of the doped snow samples. This is unfeasible, because the thickness of an ice monolayer is roughly $0.3 \mathrm{~nm}$. Whether the unreactive fraction of the bromide is located in a solid solution or in micro-pockets within the ice matrix is beyond the scope of this work, and both compartments explain its nonreactivity.

\section{Quantifying the bromide loss}

Generally, the products and reaction mechanism of the bromide oxidation by ozone in the aqueous phase strongly depend on reaction time, reactant concentration, and $\mathrm{pH}$ (Haag and Hoigne, 1983; Heeb et al., 2014). For nonacidified conditions, such as those in our study, hypobromous acid $\left(\mathrm{HOBr} / \mathrm{OBr}^{-}\right)$is the main product (Reaction $\left.\mathrm{R} 1\right)$ that may react further with ozone (Reaction R2) to form bromite $\left(\mathrm{BrO}_{2}^{-}\right)$, disproportionate to bromide $\left(\mathrm{Br}^{-}\right)$and bromate $\left(\mathrm{BrO}_{3}^{-}\right)$, or self-react to dibromine monoxide $\left(\mathrm{Br}_{2} \mathrm{O}\right.$; Heeb et al., 2014). Despite uncertainties in the precise product distribution in this study, ozone is lost in the initial reaction with bromide and, to some extent, in the subsequent oxidation of hypobromous acid to bromite resulting in 12 ozone molecules lost per bromide ion. In particular, under acidic conditions, such as those relevant for atmospheric waters and ices (Abbatt et al., 2012; Bartels-Rausch et al., 2014), bromine is formed and released to the atmosphere in a sequence of reaction steps (Reactions R1 and R3):

$$
\begin{aligned}
& \mathrm{Br}^{-}+\mathrm{O}_{3} \longrightarrow \mathrm{OBr}^{-}+\mathrm{O}_{2} \\
& \mathrm{OBr}^{-}+\mathrm{O}_{3} \longrightarrow \mathrm{BrO}_{2}^{-}+\mathrm{O}_{2} \\
& \mathrm{OBr}^{-}+\mathrm{Br}^{-}+\mathrm{H}^{+} \longrightarrow \mathrm{Br}_{2}+\mathrm{OH}^{-}
\end{aligned}
$$

Thus, assuming a net loss of 1 ozone molecule per bromide molecule, one might estimate that about $0.9 \times 10^{16}$ and
$1.7 \times 10^{16}$ molecules of bromide are available for the multiphase reaction with ozone in the two porous snow samples prior to metamorphism. Assuming a net loss of 2 ozone molecules, $1.8 \times 10^{16}$ and $3.3 \times 10^{16}$ molecules of available bromide can be estimated for the two samples. The cumulative loss was derived by integrating the area below the loss rate curves in Fig. 1 between 500 and $8000 \mathrm{~s}$ and subtracting the cumulative loss of the undoped sample to account for the presence of impurities in the samples doped with bromide. For this analysis, the missing data during periods where the carrier gas was bypassing the snow to monitor the ozone concentration delivered to the flow tube were estimated using a power fit to the data (Fig. 1). The cumulative amount of reacted bromide can be compared to the total amount of bromide of $4 \times 10^{16}$ and $6 \times 10^{16}$ molecules initially added to the snow sample; apparently, a maximum of $22 \%-26 \%$ and $44 \%-52 \%$ of the bromide was accessible to gas-phase ozone prior to metamorphism.

\section{Structural changes to the snow}

Table 1 lists the physical properties of the snow samples. The specific surface area (SSA) and the porosity are within the range observed for hard wind-packed snow and depth hoar in the field (Legagneux et al., 2002; Zermatten et al., 2011; Calonne et al., 2012). The structural changes in the snow during the $12 \mathrm{~d}$ temperature gradient metamorphism are visualized using X-ray microtomography (microCT) images in Fig. 2. In the microCT image of the snow sample prior to metamorphism, individual spheres with a 300-600 $\mu \mathrm{m}$ diameter are visible (Fig. 2a). With developing snow metamorphism, the spheres become increasingly bonded and a new porous snow structure forms, while the recognition of the 
individual snow particles is lost (Fig. 2b). This reconstruction is a direct consequence of the temperature gradient in snow resulting in water vapour pressure gradients that induce fluxes of water vapour from warmer to colder regions. In the experiments described here, the locally and continuously sublimating and growing snow, with an ice growth rate of $2 \mathrm{~nm} \mathrm{~s}^{-1}$ (Trachsel et al., 2019), leads to about five complete renewal cycles of the snow structure during the $12 \mathrm{~d}$ temperature gradient metamorphism (Pinzer et al., 2012). The fact that changes in SSA do not necessarily reflect water turnover rates during metamorphism has been discussed before (Pinzer et al., 2012). The samples that were stored isothermally at $-5^{\circ} \mathrm{C}$ for $7 \mathrm{~d}$ and for up to $54 \mathrm{~d}$ at $-45^{\circ} \mathrm{C}$ prior to the metamorphism experiments (Fig. 2a) also show facets, which is typical for isothermal snow (Kämpfer et al., 2005; Löwe et al., 2011).

The observed burial of bromide during the temperature gradient metamorphism may be attributed to a combination of growing ice, covering the bromide present at the air-ice interface with neat ice, and the diffusion of the bromide into the growing ice as described in our previous work (Trachsel et al., 2019). Whether the bromide remains agglomerated, forming micro-pockets under the growing ice, or forms a solid solution in the growing ice remains speculative. A recent study by $\mathrm{Wu}$ et al. (2017) showed that bromide is likely to be incorporated into the ice with recrystallization especially at a low concentration. Molecular dynamics simulations by Wu et al. (2017) showed that the charge density around a bromide ion does not result in very large disruptions of the local ice structure. Therefore, they concluded that incorporating bromide into the ice structure may be energetically feasible. Patches at the interface may also be covered by the growing ice in line with Nagashima et al. (2018), who observed preferential growth of ice onto brine droplets compared with the neat ice surface.

The results presented here show that after five complete recrystallization cycles the bromide is absent from the airice interface. This depletion of bromide at the air-ice interface is in excellent agreement with previous observations of other ions in snow during metamorphism (Hewitt et al., 1991; Cragin et al., 1996; Trachsel et al., 2019). Elution profiles of shock-frozen snow doped with a mixture of ammonium, calcium, chloride, fluoride, sodium, and sulfate revealed decreasing amounts of all ions at the air-ice interface with a duration of snow metamorphism up to $12 \mathrm{~d}$ (Trachsel et al., 2019). On longer timescales, calcium and sulfate showed increasing occurrence at the air-ice interface. A further finding from Trachsel et al., 2019 is that cations and anions tend to experience the same fate in shock-frozen snow. Thus, one might speculate that the sodium in the experiments presented here is also depleted at the air-ice interface during metamorphism. A more detailed and quantitative comparison with the elution studies is hampered, as these studies generally lack a budget of ions and give no direct link to chemical reactivity. Further, meltwater or the eluent induces changes to the snow (a)

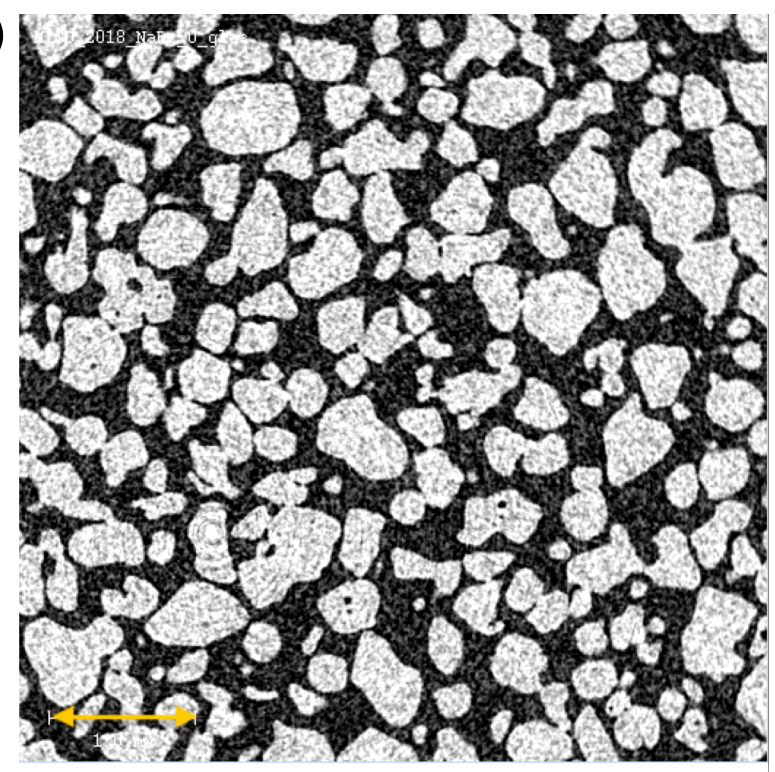

(b)

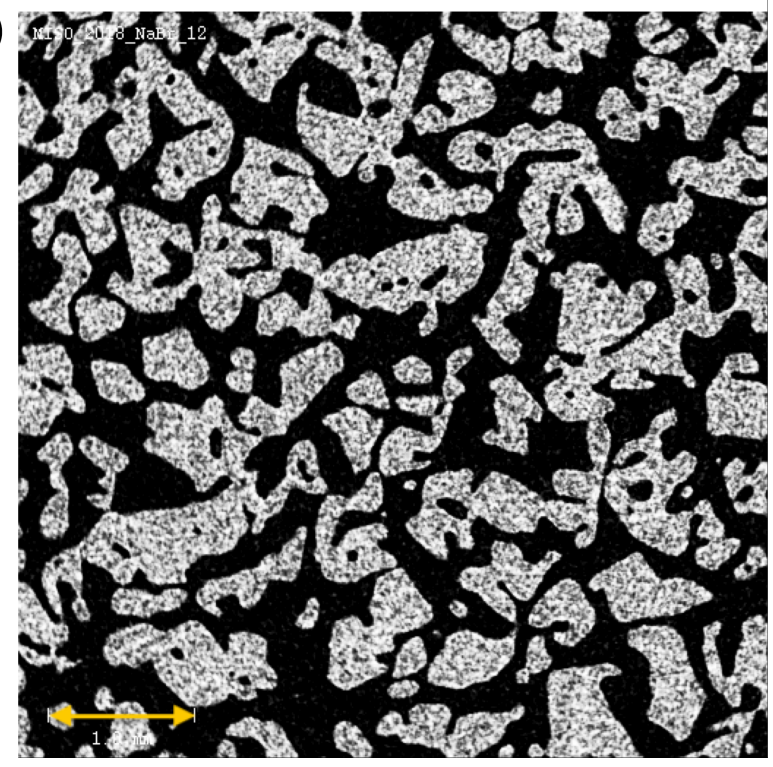

Figure 2. MicroCT images showing cross sections of the doped snow samples after $0 \mathrm{~d}$ (a) and $12 \mathrm{~d}$ (b) exposure to temperature gradient metamorphism. White areas show the ice phase, and black represents interstitial air. The scale bar (yellow arrow) denotes $1 \mathrm{~mm}$.

structure (wet metamorphism) and might lead to the relocation of impurities (Meyer and Wania, 2008; Grannas et al., 2013).

\section{Conclusions and atmospheric implication}

We have presented an assessment of the effects of metamorphism on the loss of gas-phase ozone in bromide-doped snow. Probing the presence of bromide in snow by its reac- 
tion with ozone is an effective way to reveal its location compared with other methods that would offer more chemical selectivity or spatial resolution but lack sensitivity for the low impurity concentrations found in the environment. Experiments were performed in the dark in snow doped with $6.2 \mu \mathrm{M}$ sodium bromide. The artificial snow had physical properties and a bromide concentration typical of natural snow, making extrapolations to the environment feasible. While snow is not formed by shock freezing in the environment, riming might occur and may lead to a similar distribution of impurities as that observed in our samples. Further, we suggest that the patches of bromide at the air-ice interface represent bromide that is deposited with sea salt aerosol on surface snow. Our observation of the ozone consumption showed that the bromide-doped snow samples lost their chemical reactivity towards gas-phase ozone during $12 \mathrm{~d}$ of temperature gradient metamorphism. This loss occurred without photochemistry forming volatile products. Post-depositional changes to bromide in snow have been observed in the field and have, thus far, been explained by vivid photochemical reaction into volatile bromine. Volatile bromine might then be redeposited on the snow surface after the formation of more oxidized species, such as HOBr (Jacobi et al., 2002; Toom-Sauntry and Barrie, 2002). The burial of volatile trace gases into growing ice has also been discussed for acidic trace gases with atmospheric relevance (Huthwelker et al., 2006). Kippenberger et al. (2019) studied the uptake of $\mathrm{HCl}$ and of oxidized organic trace gases to growing ice in Knudsen cell experiments. They observed a continuous uptake of $\mathrm{HCl}$ that exceeded the equilibrium partitioning of $\mathrm{HCl}$ to ice (Zimmermann et al., 2016) scaling with ice growth rate and temperature. Growth rates were varied between 2 and $110 \mathrm{~nm} \mathrm{~s}^{-1}$. In this study, we uniquely show that non-volatile bromide ions are effectively buried. Apparently, temperature gradient metamorphism appears to facilitate the formation of the energetically most favourable impurity distributions in snow.

Our findings directly imply that where temperature gradients are omnipresent in Earth surface snow, the burial of non-volatile solutes during metamorphism can reduce their availability for heterogeneous reactions. The fact that only a small fraction of impurities may be chemically active in surface snow has been discussed for nitrate by Thomas et al. (2011) and Wren and Donaldson (2011). Thus, results from this study emphasize that the reactivity of impurities changes dramatically with time during temperature gradient metamorphism in the field, rather than being a result of the initial deposition process.

Clearly, the tendency to be incorporated into the ice matrix is a strong function of the chemical properties and of concentration (Bartels-Rausch et al., 2014; Trachsel et al., 2019). As a consequence, chemical species that were initially deposited together to the snow might separate to different compartments during metamorphism. The fact that bromide, for example, is driven into the ice while other potential reaction partners might leave the ice may lead to the deactivation of other reaction pathways. For instance, oxidation by $\mathrm{OH}$ radicals that are produced from organics ending up outside - too far away for the $\mathrm{OH}$ to reach the bromide.

We argued that the driving forces for this relocation are temperature inhomogeneities and the resulting water vapour fluxes, which are frequently observed in surface snow. Moreover, the fact that ice is not in thermodynamic equilibrium is a common situation for atmospheric ice particles, owing to the sub- and supersaturation conditions that they experience (Gao et al., 2004). Therefore, our results suggest that a similar redistribution of ions might also occur prior to snowfall.

In the case of bromide, redistribution away from the interface will suppress an initiation step in bromine explosion and ozone depletion events, under both light and dark conditions, even for snow samples that show high bromide concentrations. We propose that this finding - at least partially - explains the varying reactivity of Arctic surface snow. Pratt et al. (2013) investigated the production of bromine for a range of saline snow and sea ice samples in outdoor chamber experiments and found no correlation with the total bromide concentration in the samples and bromine release. It appeared that pristine snow, where exchange with the atmosphere dominates the chemical composition, is more productive than snow that is in contact with sea water. Pratt et al. (2013) argued that deposition of atmospheric acids to the unbuffered surface snow drives the observed reactivity. Based on our finding, another explanation would be a constant flux of bromide from the atmosphere refurbishing the bromide that is buried by temperature gradient metamorphism and, thus, providing reactive bromide at the air-ice interface.

This finding has significant environmental implications, as it not only stresses the importance of the location of chemical species on their reactivity but also shows that this location is rapidly changing in surface snow. One should note that the incorporation of solutes into the interior of ice and snow not only makes them resistant to multiphase chemistry but also further reduces their tendency to be washed away by melt or by rain water percolating the snow. Thus, the enrichment in the snow may contribute to the later release of toxins to the marine food web upon complete melting of the snow (Wania et al., 1998; Eichler et al., 2001; Steffen et al., 2008; Durnford and Dastoor, 2011; Grannas et al., 2013). Further, even under current warming conditions, the buried species might be promising candidates for reconstructing past atmospheric composition from ice core records that have experienced melt effects (Eichler et al., 2001).

Data availability. Data used in this study are available at https://doi.org/10.16904/envidat.138. Data set on bromide oxidation by ozone in snow during metamorphism from laboratory study, EnviDat. (Jacinta Edebeli and Thorsten Bartels-Rausch, 2020). 
Author contributions. TBR, AE, and MS designed the MISO project that this study was part of. JE planned and performed the flow tube experiments with help and input from MA, AE, MS, SA, and TBR. JT and JE performed, analysed, and discussed the microCT measurements with input from MS. TBR and JE analysed the ozone uptake data and wrote the paper with input from all coauthors. All authors approved the submitted version of the paper. This work is part of JE's doctoral thesis at ETH Zürich.

Competing interests. The authors declare that they have no conflict of interest.

Acknowledgements. The authors wish to thank Matthias Jaggi (SLF) and Mario Birrer (PSI) for their technical assistance. We are also grateful to Margret Matzl (SLF) for her help with evaluating the microCT data.

Financial support. This research has been supported by the Swiss National Science Foundation (SNSF; grant no. 155999).

Review statement. This paper was edited by Hinrich Grothe and reviewed by three anonymous referees.

\section{References}

Abbatt, J. P. D., Oldridge, N. W., Symington, A., Chukalovskiy, V., McWhinney, R. D., Sjostedt, S. J., and Cox, R. A.: Release of gas-phase halogens by photolytic generation of $\mathrm{OH}$ in frozen halide-nitrate solutions: An active halogen formation mechanism?, J. Phys. Chem. A., 114, 6527-6533, https://doi.org/10.1021/jp102072t, 2010.

Abbatt, J. P. D., Thomas, J. L., Abrahamsson, K., Boxe, C., Granfors, A., Jones, A. E., King, M. D., Saiz-Lopez, A., Shepson, P. B., Sodeau, J., Toohey, D. W., Toubin, C., von Glasow, R., Wren, S. N., and Yang, X.: Halogen activation via interactions with environmental ice and snow in the polar lower troposphere and other regions, Atmos. Chem. Phys., 12, 6237-6271, https://doi.org/10.5194/acp-12-6237-2012, 2012.

Artiglia, L., Edebeli, J., Orlando, F., Chen, S., Lee, M.-T., Corral Arroyo, P., Gilgen, A., Bartels-Rausch, T., Kleibert, A., Vazdar, M., Carignano, M. A., Francisco, J. S., Shepson, P. B., Gladich, I., and Ammann, M.: A surface-stabilized ozonide triggers bromide oxidation at the aqueous solution-vapour interface, Nat. Commun., 8, 700, https://doi.org/10.1038/s41467-017-00823-x, 2017

Bartels-Rausch, T., Guimbaud, C., Gäggeler, H. W., and Ammann, M.: The partitioning of acetone to different types of ice and snow between 198 and 223 K, Geophys. Res. Lett., 31, L16110, https://doi.org/10.1029/2004g1020070, 2004.

Bartels-Rausch, T., Huthwelker, T., Gäggeler, H. W., and Ammann, M.: Atmospheric pressure coated-wall flow-tube study of acetone adsorption on ice, J. Phys. Chem. A., 109, 4531-4539, https://doi.org/10.1021/jp0451871, 2005.
Bartels-Rausch, T., Jacobi, H.-W., Kahan, T. F., Thomas, J. L., Thomson, E. S., Abbatt, J. P. D., Ammann, M., Blackford, J. R., Bluhm, H., Boxe, C., Domine, F., Frey, M. M., Gladich, I., Guzmán, M. I., Heger, D., Huthwelker, Th., Klán, P., Kuhs, W. F., Kuo, M. H., Maus, S., Moussa, S. G., McNeill, V. F., Newberg, J. T., Pettersson, J. B. C., Roeselová, M., and Sodeau, J. R.: A review of air-ice chemical and physical interactions (AICI): liquids, quasi-liquids, and solids in snow, Atmos. Chem. Phys., 14, 1587-1633, https://doi.org/10.5194/acp-14-1587-2014, 2014.

Bartels-Rausch, T., Orlando, F., Kong, X., Artiglia, L., and Ammann, M.: Experimental evidence for the formation of solvation shells by soluble species at a nonuniform air-ice interface, ACS Earth Space Chem., 1, 572-579, https://doi.org/10.1021/acsearthspacechem.7b00077, 2017.

Birkeland, K. W., Johnson, R. F., and Schmidt, S. D.: Near-surface faceted crystals formed by diurnal recrystallization: A case study of weak layer formation in the mountain snowpack and its contribution to snow avalanches, Arct. Alp. Res., 30, 200-204, https://doi.org/10.2307/1552135, 1998.

Blackford, J. R.: Sintering and microstructure of ice: A review, J. Phys. D: Appl. Phys., 40, R355-R385, https://doi.org/10.1088/0022-3727/40/21/R02, 2007.

Blackford, J. R., Jeffree, C. E., Noake, D. F. J., and Marmo, B. A.: Microstructural evolution in sintered ice particles containing $\mathrm{NaCl}$ observed by low-temperature scanning electron microscope, Proc. Inst. Mech. Eng, 221, 151-156, https://doi.org/10.1243/14644207JMDA134, 2007.

Calonne, N., Geindreau, C., Flin, F., Morin, S., Lesaffre, B., Rolland du Roscoat, S., and Charrier, P.: 3-D image-based numerical computations of snow permeability: links to specific surface area, density, and microstructural anisotropy, The Cryosphere, 6, 939-951, https://doi.org/10.5194/tc-6-939-2012, 2012.

Cragin, J. H., Hewitt, A. D., and Colbeck, S. C.: Grain-scale mechanisms influencing the elution of ions from snow, Atmos. Environ., 30, 119-127, https://doi.org/10.1016/1352-2310(95)00232N, 1996.

Crowley, J. N., Ammann, M., Cox, R. A., Hynes, R. G., Jenkin, M. E., Mellouki, A., Rossi, M. J., Troe, J., and Wallington, T. J.: Evaluated kinetic and photochemical data for atmospheric chemistry: Volume V - heterogeneous reactions on solid substrates, Atmos. Chem. Phys., 10, 9059-9223, https://doi.org/10.5194/acp-10-9059-2010, 2010.

Dominé, F. and Rey-Hanot, L.: Adsorption isotherms of acetone on ice between 193 and 213 K, Geophys. Res. Lett., 29, 1873 , https://doi.org/10.1029/2002GL015078, 2002.

Dominé, F. and Shepson, P. B.: Air-snow interactions and atmospheric chemistry, Science, 297, 1506-1510, https://doi.org/10.1126/science.1074610, 2002.

Domine, F., Albert, M., Huthwelker, T., Jacobi, H.-W., Kokhanovsky, A. A., Lehning, M., Picard, G., and Simpson, W. R.: Snow physics as relevant to snow photochemistry, Atmos. Chem. Phys., 8, 171-208, https://doi.org/10.5194/acp-8171-2008, 2008.

Domine, F., Barrere, M., Sarrazin, D., Morin, S., and Arnaud, L.: Automatic monitoring of the effective thermal conductivity of snow in a low-Arctic shrub tundra, The Cryosphere, 9, 12651276, https://doi.org/10.5194/tc-9-1265-2015, 2015.

Durnford, D. and Dastoor, A.: The behavior of mercury in the cryosphere: A review of what we know 
from observations, J. Geophys. Res., 116, D06305, https://doi.org/10.1029/2010jd014809, 2011.

Ebner, P. P., Steen-Larsen, H. C., Stenni, B., Schneebeli, M., and Steinfeld, A.: Experimental observation of transient $\delta^{18} \mathrm{O}$ interaction between snow and advective airflow under various temperature gradient conditions, The Cryosphere, 11, 1733-1743, https://doi.org/10.5194/tc-11-1733-2017, 2017.

Edebeli, J. and Bartels-Rausch, T.: Data set on bromide oxidation by ozone in snow during metamorphism from laboratory study, EnviDat, https://doi.org/10.16904/envidat.138, 2020.

Edebeli, J., Ammann, M., and Bartels-Rausch, T.: Microphysics of the aqueous bulk counters the water activity driven rate acceleration of bromide oxidation by ozone from 289-245 K, Environ. Sci.-Proc. Imp., 21, 63-73, https://doi.org/10.1039/c8em00417j, 2019.

Eichler, A., Schwikowski, M., and Gäggeler, H. W.: Meltwaterinduced relocation of chemical species in alpine firn, Tellus B, 53, 192-203, https://doi.org/10.1034/j.1600-0889.2001.d0115.x, 2001.

Gao, R. S., Fahey, D. W., Kärcher, B., and Peter, T.: Evidence that nitric acid increases relative humidity in low-temperature cirrus clouds, Science, 303, 516-520, https://doi.org/10.1126/science.1091255, 2004.

Grannas, A. M., Bogdal, C., Hageman, K. J., Halsall, C., Harner, T., Hung, H., Kallenborn, R., Klán, P., Klánová, J., Macdonald, R. W., Meyer, T., and Wania, F.: The role of the global cryosphere in the fate of organic contaminants, Atmos. Chem. Phys., 13, 32713305, https://doi.org/10.5194/acp-13-3271-2013, 2013.

Haag, W. R. and Hoigne, J.: Ozonation of bromidecontaining waters: Kinetics of formation of hypobromous acid and bromate, Environ. Sci. Technol., 17, 261-267, https://doi.org/10.1021/es00111a004, 1983.

Hagenmuller, P., Chambon, G., Flin, F., Morin, S., and Naaim, M.: Snow as a granular material: Assessment of a new grain segmentation algorithm, Granul. Matter, 16, 421-432, https://doi.org/10.1007/s10035-014-0503-7, 2014.

Hagenmuller, P., Flin, F., Dumont, M., Tuzet, F., Peinke, I., Lapalus, P., Dufour, A., Roulle, J., Pézard, L., Voisin, D., Ando, E., Rolland du Roscoat, S., and Charrier, P.: Motion of dust particles in dry snow under temperature gradient metamorphism, The Cryosphere, 13, 2345-2359, https://doi.org/10.5194/tc-13-23452019, 2019.

Heeb, M. B., Criquet, J., Zimmermann-Steffens, S. G., and von Gunten, U.: Oxidative treatment of bromide-containing waters: Formation of bromine and its reactions with inorganic and organic compounds - a critical review, Water Res., 48, 15-42, https://doi.org/10.1016/j.watres.2013.08.030, 2014.

Hewitt, A. D., Cragin, J. H., and Colbeck, S. C.: Does snow have ion chromatographic properties?, 46th Ann. Eastern Snow Conference, Quebec City, Quebec, Canada, 8 to 9 June 1989, 19, 165-171, 1989.

Hewitt, A. D., Cragin, J. H., and Colbeck, S. C.: Effects of crystal metamorphosis on the elution from chemical species from snow, 48th Ann. Eastern Snow Conference, Guelph, Ontario, Canada, 5 to 7 June 1991, 1, 1-10, 1991.

Hullar, T. and Anastasio, C.: Direct visualization of solute locations in laboratory ice samples, The Cryosphere, 10, 2057-2068, https://doi.org/10.5194/tc-10-2057-2016, 2016.
Huthwelker, T., Ammann, M., and Peter, T.: The uptake of acidic gases on ice, Chem. Rev., 106, 1375-1444, https://doi.org/10.1021/Cr020506v, 2006.

Jacobi, H.-W., Frey, M. M., Hutterli, M. A., Bales, R. C., Schrems, O., Cullen, N. J., Steffen, K., and Koehler, C.: Measurements of hydrogen peroxide and formaldehyde exchange between the atmosphere and surface snow at Summit, Greenland, Atmos. Environ., 36, 2619-2628, https://doi.org/10.1016/S13522310(02)00106-1, 2002.

Jacobi, H.-W., Voisin, D., Jaffrezo, J. L., Cozic, J., and Douglas, T. A.: Chemical composition of the snowpack during the OASIS spring campaign 2009 at Barrow, Alaska, J. Geophys. Res., 117, D00R13, https://doi.org/10.1029/2011JD016654, 2012.

Kämpfer, T. U., Schneebeli, M., and Sokratov, S. A.: A microstructural approach to model heat transfer in snow, Geophys. Res. Lett., 32, L21503, https://doi.org/10.1029/2005GL023873, 2005.

Kärcher, B. and Basko, M. M.: Trapping of trace gases in growing ice crystals, J. Geophys. Res., 109, D22204, https://doi.org/10.1029/2004JD005254, 2004.

Kerbrat, M., Huthwelker, T., Gäggeler, H. W., Ammann, M., and Schneebeli, M.: Measuring the specific surface area of snow with $\mathrm{X}$-ray tomography and gas adsorption: Comparison and implications for surface smoothness, Atmos. Chem. Phys., 8, 12611275, https://doi.org/10.5194/acp-8-1261-2008, 2008.

Kippenberger, M., Schuster, G., Lelieveld, J., and Crowley, J. N.: Trapping of $\mathrm{HCl}$ and oxidised organic trace gases in growing ice at temperatures relevant to cirrus clouds, Atmos. Chem. Phys., 19, 11939-11951, https://doi.org/10.5194/acp-19-119392019, 2019.

Kong, X., Waldner, A., Orlando, F., Artiglia, L., Huthwelker, T., Ammann, M., and Bartels-Rausch, T.: Coexistence of physisorbed and solvated $\mathrm{HCl}$ at warm ice surfaces, J. Phys. Chem. Lett., 8, 4757-4762, https://doi.org/10.1021/acs.jpclett.7b01573, 2017.

Krepelova, A., Bartels-Rausch, T., Brown, M. A., Bluhm, H., and Ammann, M.: Adsorption of acetic acid on ice studied by ambient-pressure XPS and partial-electron-yield NEXAFS spectroscopy at 230-240 K, J. Phys. Chem. A, 117, 401-409, https://doi.org/10.1021/jp3102332, 2013.

Langenberg, S. and Schurath, U.: Ozone destruction on ice, Geophys. Res. Lett., 26, 1695-1698, https://doi.org/10.1029/1999g1900325, 1999.

Legagneux, L., Cabanes, A., and Dominé, F.: Measurement of the specific surface area of 176 snow samples using methane adsorption at $77 \mathrm{~K}$, J. Geophys. Res., 107, 4335, https://doi.org/10.1029/2001JD001016, 2002.

Löwe, H., Spiegel, J. K., and Schneebeli, M.: Interfacial and structural relaxations of snow under isothermal conditions, J. Glaciol., 57, 499-510, https://doi.org/10.3189/002214311796905569, 2011.

McFall, A. S., Edwards, K. C., and Anastasio, C.: Nitrate photochemistry at the air-ice interface and in other ice reservoirs, Environ. Sci. Technol., 52, 5710-5717, https://doi.org/10.1021/acs.est.8b00095, 2018.

Meyer, T. and Wania, F.: Organic contaminant amplification during snowmelt, Water Res., 42, 1847-1865, https://doi.org/10.1016/j.watres.2007.12.016, 2008.

Nagashima, K., Sazaki, G., Hama, T., Murata, K.-i., and Furukawa, Y.: Uptake mechanism of atmospheric hydrogen chloride gas in 
ice crystals via hydrochloric acid droplets, Cryst. Growth Des., 18, 4117-4122, https://doi.org/10.1021/acs.cgd.8b00531, 2018.

Oldridge, N. W. and Abbatt, J. P. D.: Formation of gas-phase bromine from interaction of ozone with frozen and liquid $\mathrm{NaCl} / \mathrm{NaBr}$ solutions: Quantitative separation of surficial chemistry from bulk-phase reaction, J. Phys. Chem. A., 115, 25902598, https://doi.org/10.1021/jp200074u, 2011.

Peybernes, N., Marchand, C., Le Calve, S., and Mirabel, P.: Adsorption studies of acetone and 2,3-butanedione on ice surfaces between 193 and 223 K, Phys. Chem. Chem. Phys., 6, 1277-1284, https://doi.org/10.1039/b315064j, 2004.

Pinzer, B. and Schneebeli, M.: Breeding snow: An instrumented sample holder for simultaneous tomographic and thermal studies, Meas. Sci. Technol., 20, 095705, https://doi.org/10.1088/09570233/20/9/095705, 2009.

Pinzer, B. R., Schneebeli, M., and Kaempfer, T. U.: Vapor flux and recrystallization during dry snow metamorphism under a steady temperature gradient as observed by time-lapse micro-tomography, The Cryosphere, 6, 1141-1155, https://doi.org/10.5194/tc-6-1141-2012, 2012.

Pratt, K. A., Custard, K. D., Shepson, P. B., Douglas, T. A., Pöhler, D., General, S., Zielcke, J., Simpson, W. R., Platt, U., Tanner, D. J., Gregory Huey, L., Carlsen, M., and Stirm, B. H.: Photochemical production of molecular bromine in arctic surface snowpacks, Nat. Geosi., 6, 351-356, https://doi.org/10.1038/ngeo1779, 2013.

Riche, F., Bartels-Rausch, T., Schreiber, S., Ammann, M., and Schneebeli, M.: Temporal evolution of surface and grain boundary area in artificial ice beads and implications for snow chemistry, J. Glaciol., 58, 815-817, https://doi.org/10.3189/2012JoG12J058, 2012.

Rumble, J. (Ed.): CRC handbook of chemistry and physics, 100th edition, in: CRC Press/Taylor \& Francis, Boca Raton, FL, ISBN 978-1-1383-6729-6, 2019.

Saiz-Lopez, A. and von Glasow, R.: Reactive halogen chemistry in the troposphere, Chem. Soc. Rev., 41, 6448-6472, https://doi.org/10.1039/C2CS35208G, 2012.

Schmidt, J. A., Jacob, D., Horowitz, H. M., Hu, L., Sherwen, T., Evans, M. J., Liang, Q., Suleiman, R. M., Oram, D. E., Le Breton, M., Percival, C. J., Wang, S., Dix, B., and Volkamer, R.: Modeling the observed tropospheric BrO background: Importance of multiphase chemistry and implications for ozone, OH, and mercury, J. Geophys. Res., 121, 11819-11835, https://doi.org/10.1002/2015JD024229, 2016.

Schweizer, J.: Snow and avalanche research: A journey across scales, Cold Reg. Sci. Technol., 108, 69-71, https://doi.org/10.1016/j.coldregions.2014.09.011, 2014.

Simpson, W. R., von Glasow, R., Riedel, K., Anderson, P., Ariya, P., Bottenheim, J., Burrows, J., Carpenter, L. J., Frieß, U., Goodsite, M. E., Heard, D., Hutterli, M., Jacobi, H.-W., Kaleschke, L., Neff, B., Plane, J., Platt, U., Richter, A., Roscoe, H., Sander, R., Shepson, P., Sodeau, J., Steffen, A., Wagner, T., and Wolff, E.: Halogens and their role in polar boundary-layer ozone depletion, Atmos. Chem. Phys., 7, 4375-4418, https://doi.org/10.5194/acp7-4375-2007, 2007.

Simpson, W. R., Brown, S. S., Saiz-Lopez, A., Thornton, J. A., and von Glasow, R.: Tropospheric halogen chemistry: Sources, cycling, and impacts, Chem. Rev., 115, 4035-4062, https://doi.org/10.1021/cr5006638, 2015.
Steen-Larsen, H. C., Johnsen, S. J., Masson-Delmotte, V., Stenni, B., Risi, C., Sodemann, H., Balslev-Clausen, D., Blunier, T., Dahl-Jensen, D., Ellehøj, M. D., Falourd, S., Grindsted, A., Gkinis, V., Jouzel, J., Popp, T., Sheldon, S., Simonsen, S. B., Sjolte, J., Steffensen, J. P., Sperlich, P., Sveinbjörnsdóttir, A. E., Vinther, B. M., and White, J. W. C.: Continuous monitoring of summer surface water vapor isotopic composition above the Greenland Ice Sheet, Atmos. Chem. Phys., 13, 4815-4828, https://doi.org/10.5194/acp-13-4815-2013, 2013.

Steen-Larsen, H. C., Masson-Delmotte, V., Hirabayashi, M., Winkler, R., Satow, K., Prié, F., Bayou, N., Brun, E., Cuffey, K. M., Dahl-Jensen, D., Dumont, M., Guillevic, M., Kipfstuhl, S., Landais, A., Popp, T., Risi, C., Steffen, K., Stenni, B., and Sveinbjörnsdottír, A. E.: What controls the isotopic composition of Greenland surface snow?, Clim. Past, 10, 377-392, https://doi.org/10.5194/cp-10-377-2014, 2014.

Steffen, A., Douglas, T., Amyot, M., Ariya, P., Aspmo, K., Berg, T., Bottenheim, J., Brooks, S., Cobbett, F., Dastoor, A., Dommergue, A., Ebinghaus, R., Ferrari, C., Gardfeldt, K., Goodsite, M. E., Lean, D., Poulain, A. J., Scherz, C., Skov, H., Sommar, J., and Temme, C.: A synthesis of atmospheric mercury depletion event chemistry in the atmosphere and snow, Atmos. Chem. Phys., 8, 1445-1482, https://doi.org/10.5194/acp-8-1445-2008, 2008.

Stephen, H. and Stephen, T.: Solubility of various compounds in water, in: Binary systems, edited by: Stephen, H. and Stephen, T., Pergamon, 1, 5-960, Elsevier, 978-0-0800-9923-1, https://doi.org/10.1016/B978-0-08-009923-1.50006-9, 1963.

Thibert, E. and Dominé, F.: Thermodynamics and kinetics of the solid solution of $\mathrm{HCl}$ in ice, J. Phys. Chem. B., 101, 3554-3565, https://doi.org/10.1021/jp962115o, 1997.

Thibert, E. and Dominé, F.: Thermodynamics and kinetics of the solid solution of $\mathrm{HNO}_{3}$ in ice, J. Phys. Chem. B, 102, 4432 4439, https://doi.org/10.1021/jp980569a, 1998.

Thomas, J. L., Stutz, J., Lefer, B., Huey, L. G., Toyota, K., Dibb, J. E., and von Glasow, R.: Modeling chemistry in and above snow at Summit, Greenland - Part 1: Model description and results, Atmos. Chem. Phys., 11, 4899-4914, https://doi.org/10.5194/acp11-4899-2011, 2011.

Toom-Sauntry, D. and Barrie, L. A.: Chemical composition of snowfall in the high arctic: 1990-1994, Atmos. Environ., 36, 2683-2693, https://doi.org/10.1016/S1352-2310(02)001152, 2002.

Trachsel, J. C., Avak, S. E., Edebeli, J., Schneebeli, M., BartelsRausch, T., Bruetsch, S., and Eichler, A.: Microscale rearrangement of ammonium induced by snow metamorphism, Front. Earth Sci., 7, 194, https://doi.org/10.3389/feart.2019.00194, 2019.

Ullerstam, M. and Abbatt, J. P. D.: Burial of gas-phase $\mathrm{HNO}_{3}$ by growing ice surfaces under tropospheric conditions, Phys. Chem. Chem. Phys., 7, 3596-3600, https://doi.org/10.1039/b507797d, 2005.

Waldner, A., Artiglia, L., Kong, X., Orlando, F., Huthwelker, T., Ammann, M., and Bartels-Rausch, T.: Pre-melting and the adsorption of formic acid at the air-ice interface at $253 \mathrm{~K}$ as seen by NEXAFS and XPS, Phys. Chem. Chem. Phys., 20, 2440824417, https://doi.org/10.1039/C8CP03621G, 2018.

Wania, F., Hoff, J. T., Jia, C. Q., and Mackay, D.: The effects of snow and ice on the environmental behaviour of hy- 
drophobic organic chemicals, Environ. Pollut., 102, 25-41, https://doi.org/10.1016/S0269-7491(98)00073-6, 1998.

Winkler, A. K., Holmes, N. S., and Crowley, J. N.: Interaction of methanol, acetone and formaldehyde with ice surfaces between 198 and 223 K, Phys. Chem. Chem. Phys., 4, 5270-5275, https://doi.org/10.1039/b206258e, 2002.

Wren, S. N. and Donaldson, D. J.: Exclusion of nitrate to the air-ice interface during freezing, J. Phys. Chem. Lett., 2, 1967-1971, https://doi.org/10.1021/Jz2007484, 2011.

Wren, S. N., Kahan, T. F., Jumaa, K. B., and Donaldson, D. J.: Spectroscopic studies of the heterogeneous reaction between $\mathrm{O}_{3}(\mathrm{~g})$ and halides at the surface of frozen salt solutions, J. Geophys. Res., 115, 660, https://doi.org/10.1029/2010JD013929, 2010.

Wren, S. N., Donaldson, D. J., and Abbatt, J. P. D.: Photochemical chlorine and bromine activation from artificial saline snow, Atmos. Chem. Phys., 13, 9789-9800, https://doi.org/10.5194/acp13-9789-2013, 2013.
Wu, S., Zhu, C., He, Z., Xue, H., Fan, Q., Song, Y., Francisco, J. S., Zeng, X. C., and Wang, J.: Ion-specific ice recrystallization provides a facile approach for the fabrication of porous materials, Nat. Commun., 8, 1-8, https://doi.org/10.1038/ncomms15154, 2017.

Zermatten, E., Haussener, S., Schneebeli, M., and Steinfeld, A. Tomography-based determination of permeability and dupitforchheimer coefficient of characteristic snow samples, J. Glaciol., 57, 811-816, 2011.

Zimmermann, S., Kippenberger, M., Schuster, G., and Crowley, J. $\mathrm{N}$.: Adsorption isotherms for hydrogen chloride $(\mathrm{HCl})$ on ice surfaces between 190 and $220 \mathrm{~K}$, Phys. Chem. Chem. Phys., 18, 13799-13810, https://doi.org/10.1039/C6CP01962E, 2016. 